\title{
Öğretmenlik Mesleği Genel Yeterliklerinin İncelenmesi
}

\section{Examination of General Competencies for Teaching Profession}

\author{
Şule Betül TOSUNTAŞa
}

\section{Öz}

Öğretmen yeterlikleri, öğretmenlerin mesleğini etkili ve verimli bir şekilde yerine getirebilmesi için sahip olması gereken bilgi, beceri ve tutumlar olarak ifade edilmektedir. Eğitimde istenilen hedeflere ulașılması öğretmenlerin yeterlik ve nitelikleriyle ilişkili görülmekte, yapılan yeniliklerin ancak öğretmenler aracılığıyla hayata geçirilebileceği vurgulanmaktadır. Öğretmen yeterliklerinin incelenmesi, derinlemesine bilgi sunması açısından yeterliklerin birçok alanda kullanımı adına bir katkı sağlayacaktır. Bu doğrultuda çalışmanın amacı uzun bir aradan sonra güncellenmiş olan Öğretmenlik Mesleği Genel Yeterliklerinin incelenmesidir. Çalıșma nitel araştırma modeli benimsenerek gerçekleștirilmiștir. Verilerin toplanması doküman incelemesi yoluyla gerçekleştirilmiştir. Çalışma kapsamında elde edilen dokümanlar betimsel analiz tekniği kullanılarak çözümlenmiştir. Çalışmada yeterlik alanları, alt yeterlikler ve yeterlik göstergelerinin sadeleștirildiği sonucuna ulașılmıștır. Yeterlik göstergeleri somut gözlenebilir ve ölçülebilir olacak șekilde yapılandırılmamıştır. Rasyonel ve optimum düzeyde belirlenen yeterlikler ise öğretmenlerin mesleki gelişim intiyacını ortaya çıkaracak bir rol üstlenebilir. Benzer şekilde performans/yeterlik göstergelerinin öğretmenlerin gelişimini sağlayacak şekilde hazırlanması ve bu göstergelerin değerlendirmede gerçekçi şekilde kullanılması öğretmen niteliğinin arttırımasına yarar sağlayacaktır. Öğretmenler ve öğretmen adaylarına hem kılavuz hem değerlendirme kriteri işlevi görecek şekilde yapılandırıması önerilebilir.

Anahtar Kelimeler: Öğretmen Yeterlikleri, Yeterlik, Mesleki Yeterlik, Performans

\section{Abstract}

Teacher competencies are expressed as the knowledge, skills, and attitudes that teachers should have in order to fulfill their profession effectively and efficiently. Achieving the desired goals in education is considered to be related to the competencies and qualifications of teachers, and it is emphasized that innovations can only be carried out through teachers. Examining teacher competencies will contribute to ensure that competencies are used in many areas. Accordingly, the aim of the study is to examine the General Competencies for Teaching Profession, which has been updated after a long time. The study was carried out by adopting a qualitative research model. The data collection was carried out through document analysis. Documents obtained within the scope of the study were analyzed using descriptive analysis technique. It was concluded that competency areas, sub-competencies, and competency indicators were simplified. Competency indicators are not structured to be tangible, observable, and measurable. Rational and optimum competencies can play a role to reveal the professional development needs of teachers. Similarly, preparing the performance/competency indicators in a way to ensure the development of teachers and using these indicators realistically in the evaluation will benefit the increase of teacher quality. It can be proposed to be structured to use as both a guide and an evaluation criterion for teachers and prospective teachers.

Keywords: Teacher Competencies, Competency, Professional Competency, Performance

\section{Makale Hakkında}

Tür: Araştırma

Geliş Tarihi: 1 Haziran 2019

Kabul Tarihi:23 Haziran 2020 Yayın Tarihi: 4 Temmuz 2020 DOI:

Sorumlu Yazar:

Şule Betül TOSUNTAŞ

Bursa Uludağ Üniversitesi

Bursa/Türkiye

E-posta: sbtosuntas@uludag.edu.tr

\section{About the Article}

Type: Research

Received: 1 June 2020

Accepted: 23 June 2020

Published: 4 July 2020

DOI:

Correspondance Details:

Şule Betül TOSUNTAŞ

Bursa Uludag University

Bursa/Turkey.

E-mail: sbtosuntas@uludag.edu.tr

\section{Önerilen APA Atıf Biçimi / Suggested APA Citation}

Tosuntaş, Ș. B. (2020). Öğretmenlik mesleği genel yeterliklerinin incelenmesi. Academy Journal of Educational Sciences, 4(1), 53-61. http://dx.doi.org/10.31805/acjes.746234 


\section{Giriş}

Dünyada bireyin ve toplumun intiyaçlarına bağlı olarak eğitim, öğrenme, öğretme ve öğretmenlik mesleğine yüklenen anlamlar değişmektedir. Buna bağlı olarak öğretmenlere yüklenen yeni sorumluluklar bulunmaktadır. Öğretmenlik mesleği genel anlamda birçok sorumluluğu taşıyabilecek nitelikte bir meslek olmasının yanı sıra bu sorumlulukların yerine getirilebilmesi adına birçok yeterlik mesleki açıdan zorunlu hale gelmektedir. Zira öğretmenin sahip olması gerektiği düşünülen birçok nitelik, mesleki bilgi ve beceri yeterliklerin temelini oluşturmaktadır.

Yeterlik, bir mesleğin gerekliliklerinin başarılı bir şekilde yapılabilmesi adına sahip olunması gereken özellikler şekilde tanımlanmaktadır (Şişman, 2002). Şahin (2004) ise, yeterlik kavramını bir işe yönelik minimum standartlar olarak görülmesi gerektiğini ifade etmekte ve mesleki performans açısından öneminin altını çizmektedir. Yeterlik, bir kişiye belirli bir rolü oynayabilme gücünü kazandıran özelliklerin varlığı ya da bu rolü oynayabilmesini engelleyen özelliklerin yokluğu şeklinde de tanımlanmaktadır (Bursalıoğlu, 1981). Bu açıdan yeterliğin çok boyutlu olması olağan karşılanmaktadır (Ağaoğlu, Altınkurt, Yılmaz ve Karaköse, 2012). Öğretmenlik mesleği açısından, öğretmen yeterlikleri ise öğretmenlerin mesleğini etkili ve verimli bir şekilde yerine getirebilmesi için sahip olması gereken bilgi, beceri ve tutumlar olarak ifade edilmektedir (Milli Eğitim Bakanlığı [MEB], 2017).

Türkiye'de öğretmenlik mesleğinin gerektirdiği nitelik ve yeterlikler Millî Eğitim Bakanlığı tarafından belirlenmektedir ve 1739 sayılı Milli Eğitim Temel Kanunu'nda (1973) öğretmenliğin bir uzmanlık mesleği olduğu vurgulanmaktadır. Illk resmi öğretmen yeterlikleri çalışmaları 1998 yılında, YÖK ve Dünya Bankası iş birliği ile YÖK/Dünya Bankası Milli Eğitimi Geliştirme Projesi kapsamında başlamıştır. Bu çalışmalarla öğretmen yetiştirme standartları belirlenmiş ve öğretmen yeterlikleri (i) konu alanı ve alan eğitimine ilişkin yeterlikler, (ii) öğrenme öğretme sürecine ilişkin yeterlikler, (iii) öğrencilerin öğrenmelerini izleme, değerlendirme ve kayıt tutma ve (iv) tamamlayıcı mesleki yeterlikler olmak üzere 4 boyutta ele alınmıştır (MEB, 2017). Milli Eğitim Bakanlığı tarafından ilk hazırlanan öğretmen yeterlilikleri belgesi ise 1999 yılında hazırlanmaya başlanmış ve 2002 yılında yürürlüğe girmiştir. Öğretmen yeterlilikleri belgesinin eğitme-öğretme yeterlilikleri, genel kültür bilgi ve becerileri ve özel alan bilgi ve becerileri şeklinde üç başlık altında hazırlandığı bilinmektedir (MEB, 2017). Yeterlikler öğretmen yetiştirme açısından dikkate alınması adına lisans eğitimi verilen eğitim kurumlarına gönderilmiştir.

Türkiye'de daha önceden çeşitli kalkınma planlarında sinyalleri verilmiş olan öğretmen performans değerlendirme sistemine 2002 yılında pilot uygulama ile geçilmiştir (Devlet Planlama Teşkilatı, 2000; 2006; Kalkınma Bakanlığı, 2013). Okulda Performans Yönetimi adı verilen bu modelde de yeterlik kavramı performans ile ilişkilendirilerek yüksek performansı önceden bildiren karakteristik özellikler olarak ele alınmıştır. Öğretmen Yetiştirme ve Eğitimi Genel Müdürlüğü, 2002 yıında başlayan çalışmalarında çeşitli yeterlik dokümanlarını inceleyerek ortak bir anlayıș geliștirmeyi amaçlamıştır (MEB, 2017). Bu bağlamda da öğretmen yeterlikleri kapsamında öğretmende bulunması gereken yeterlik alanları, her alanın gerektirdiği alt yeterlikler ve yeterliklerin gözleneceği performans göstergeleri belirlenmiştir (EARGED, 2006). Özel alan yeterlikleri ise, ilköğretim kade- mesi için 2008 yılında; ortaöğretim kademesi için 2011 yılında yürürlüğe konulmuştur (MEB, 2017). Öğretmen yeterliklerinin kullanım alanları ise, öğretmen yetiştirme politikalarının belirlenmesi, öğretmen yetiştiren yüksek öğretim kurumlarının hizmet öncesi öğretmen yetiştirme kurumları, öğretmenlerin hizmetiçi eğitimi, öğretmenlerin seçimi, öğretmenlerin iş başarımları ve performanslarının belirlenmesi, öğretmenlerin kendileri tanıma ve kariyer gelişimleri şeklinde ifade edilmiştir (MEB, 2008).

Türk Eğitim Derneği [TED], 2009 yılında yayınladığı çalışmasında bir öğretmenin sahip olması gereken yeterlik alanlarını şu şekilde özetlemiştir:

• Öğretmenlerin öğretme öğrenme sürecinde öğretim programları ve konu alanını çok iyi bilme ve anlama,

- Öğretimi planlaması ve uygulama,

- Öğretimin etkililiğini ve öğrenci gelişimini izleme ve degerlendirme,

- Öğretim sürecini ve öğrenci davranışlarını yönetme,

- Öğretimi öğrenci özelliklerine göre uyarlama,

- Bilişim teknolojilerini etkili biçimde kullanabilme,

- Öğretme öğrenme ortamında etkili bir iletişim sağlayabilme,

Bireysel ve mesleki gelişimi planlama ve
gerçekleștirme.

- Diğer öğretmenler, veliler ve okul çalışanları ile iş birligi içinde çalışabilme,

- Etik kurallar çerçevesinde, sorumlu ve eleştirel davranabilme.

Türkiye'nin Avrupa Yeterlikler Çerçevesi'ni kabulü sonrasında tavsiye edilen ulusal yeterlik çerçevesi geliştirilmiş ve 2015 yılında Türkiye Yeterlilikler çerçevesi yürürlüğe girmiştir. Bologna Süreci kapsamında da 2011 yılında Yükseköğretim Yeterlilikler Çerçevesi kabul edilmiştir (MEB, 2017). Bahsi geçen ve benzeri gelişmeler doğrultusunda öğretmen yeterliklerinin güncellenmesi kararı alınmış ve 2017 yılında yeni Öğretmenlik Mesleği Genel Yeterlikleri belirlenmiştir. Güncellenen yeni yeterliklerde vurgulanan noktalardan biri alan yeterliklerini de içeren bütünsel bir metin olmasıdır. Bir önceki öğretmen yeterliklerine benzer şekilde kullanım alanları belirlenmiş ve kullanıma sunulmuştur. Bu bağlamda, öğretmenlerin kendi yetkinlik düzeylerini ve geliştirilmesi gereken yönlerini belirlemeleri, öğretmen adayı yetiştiren yükseköğretim kurumlarının öğretim programlarının düzenlenmesi, öğretmenlerin mesleğe kabul ve adaylık süreçleri, mesleki gelişim intiyaçlarının tespit edilmesi ve mesleki gelişime yönelik faaliyetleri planlama, öğretmen performansı değerlendirme, kariyer gelişimi ve öğretmenlik mesleğinin statüsünü güçlendirme olmak üzere çok çeşitli alanlarda kullanılacağına işaret edilmiştir (MEB, 2017).

Eğitimde istenilen hedeflere ulaşılması öğretmenlerin yeterlik ve nitelikleriyle ilişkili görülmekte, yapılan yeniliklerin ancak öğretmenler aracılığıyla hayata geçirilebileceği vurgulanmaktadır (MEB, 2017). Yeterliklerin bir öğretmende var olması gereken bilgi, beceri, tutum ve değerleri somut biçimde ortaya koymaya yönelik bir referans metin olarak ele alınacağı, üniversitelerin öğretmen yetiştirmeye yönelik derslerin belirlenmesinde kullanılacağı ifade edilmiştir. Yeterliklerin güncellendiği tarihler açısından yükseköğretim kurumlarında öğretmen yetiştirme programlarına bakıldığın- 
da son iki güncelleme ön plana çıkmaktadır. 2006-2007 akademik yılında uygulamaya konulan öğretmen yetiştirme programının güncelleme gerekçelerinden biri olarak ilköğretim programlarında yapılan değişiklikler vurgulanmakla birlikte öğretmen yeterliklerine değinilmemiştir (Yükseköğretim Kurulu [YÖK], 2007). Programlarda \%50-60 oranında alan ve alan eğitimi, \%25-30 oranında öğretmenlik meslek bilgisi ve \%15-20 oranında genel kültür derslerine yer verildiği bilgisi bulunmaktadır. En son 2018 yılında iki yıldan uzun süren bir çalıșma sonucu öğretmen yetiștirme programları yeniden güncellenmiştir. YÖK (2018) tarafından öğretmenlikle ilgili alan bilgisi, pedagoji bilgisi ve pedagojik alan bilgisi olmak üzere üç bilgi ve yeterlik alanı olduğu ifade edilmiștir. Bu program güncellenmesi izlenen yöntem altında MEB Öğretmen Yeterliklerinin incelendiği ve mevcut lisans programlarının amaç ve öğrenme çıktılarının Türkiye Yükseköğretim Yeterlikler Çerçevesi ve Öğretmen Yeterlikleri ile karşılaştırıldığı ifadelerine yer verilmiştir. Bunun yanı sıra, güncelleme gerekçelerinden biri olarak öğretmen yeterliklerinde yenilenmesi ve buna ilişkin beklentiler gösterilmiştir (YÖK, 2018). Program içeriği incelendiğinde ise, \%30-35 oranında öğretmenlik meslek bilgisi dersleri, \%15-20 oranında genel kültür dersleri ve \%45-50 oranında alan eğitimi derslerine yer verildiği görülmektedir. Can (2019), öğretmen yetiştirme sisteminin sürekli değişimini göz önünde bulundurarak öğretmen yeterliklerinin MEB tarafından belirtilen alanlarda etkili olarak kullanılamadığını öne sürmüştür.

Dünyada gerçekleştirilen öğretmen yeterliklerine yönelik çalışmalarda farklı kavramların kullanıldığı bilinmektedir. Yeterlik kavramının öğretmenin işini yapay olarak parçalaması ve teknik bir düzeye indirgeyerek kendi bağlamı ve ortamından uzaklaştırması yönünde eleştiriler sonucunda standart kavramının kullanımı yaygınlaşmıştır (TED, 2009). Türkiye'de de yeterlik kavramı kullanımasına karşın, sıklıkla nitelik, yetkinlik ve standart kavramlarının birbiri yerine kullanımasının karmaşa yarattığı bilinmektedir. Yeterlikler, öğretmenin sahip olması gereken bilgi, beceri ve tutumların davranış düzeyinde ifade edildiği ve teknik ayrıntıları içerdiği; ancak standart kavramının davranış düzeyinde ifade edilmediği bilinmektedir. ABD'de öğretmen standartları geliştiren Eyaletler arası Yeni Öğretmen Değerlendirme ve Destek Konsorsiyumu (Interstate Teacher Assessment and Support Consortium [InTASC], 2013) belirli aralıklarla öğretmenlere yönelik standartları beLirlemekte ve çeşitli eyaletlerde uygulamaya konulmaktadır. Öğrenen ve öğrenme, alan bilgisi, öğretimsel uygulamalar ve mesleki sorumluluk şeklinde dört temel altında 10 performans standardı bulunmaktadır. Belirlenen standartlar altında bilgi, beceri, tutum ve değerlerin yer aldığı temel bilgiler, önemli noktalar ve bunların davranışlara yansıması şeklinde performans göstergelerine yer verilmektedir.

Öğretmenlerin öğrenme öğretme sürecine doğrudan ve dolaylı etkileri göz önünde bulundurularak yeterliklerinin belirlenmesinin önemli olduğuna dikkat çekilmektedir (Çelik, Yorulmaz ve Çokçalışkan, 2019; Karacaoğlu, 2008). Bu doğrultuda literatürde öğretmen (Aisyah, Yuliasri ve Warsono, 2018; Çelik vd., 2019; Kararmaz ve Arslan, 2014; Pantic ve Wubbels, 2010; Rahmani ve Alyani, 2020; Taşar, 2012; Taşgın, 2010) ve öğretmen adaylarının (Aktemür Gürler ve Tekmen, 2020; Çubukçu, 2010; Demirtaş, Cömert ve Özer, 2011; Dilci ve Yıldız, 2012; Erişen ve Çeliköz, 2003; lyison ve Onur-Sezer, 2017; Karakuş, 2017; Özer ve Gelen, 2008; Şeker, Deniz ve Görgen, 2005; Yeşilyurt, 2011) yeterlik algılarını belirlemeye yönelik birçok çalışma bulunmaktadır. Bu çalışmalardan bir kısmı MEB tarafından hazırlanan öğretmen yeterlikleri referans alınarak gerçekleştirilmiştir. Öğretmenlerin veya öğretmen adaylarının yeterlik algıları, yeterlik inançları yaş, cinsiyet, eğitim durumu, sınıf düzeyi, branş, okul türü vb. birçok demografik değişken açısından da ele alınmış ve çeşitli sonuçlara ulaşılmıştır (Aktemür Gürler ve Tekmen, 2020; Çapri ve Çelikkaleli, 2008; Erişen ve Çeliköz, 2003; Mutlu, 2016; Şeker vd., 2005). Bu açıdan öğretmen yeterliklerinin hangi özelliklere göre farklılaştığına ilişkin uzlaşı sağlanmamıştır. Sıklıkla çalışılan bir alan olması nedeniyle belli aralıklarla öğretmen yeterlikleri alanında yapılan araştırmaların içerik analizlerinin yapıldığı çalışmalar da literatürde yer almaktadır (Gündoğdu, Aytaçlı, Aydoğan ve Yıldırım, 2015; Kazu ve Çam, 2019). Öğretmenlerin yeterlik düzeylerini belirleme çalışmalarının yanı sıra okulun verimliliği ve etkililiği açısından önemli bir aktör olan okul yöneticilerinin yeterliliklerini belirlemek adına da ulusal ve uluslararası birçok araştırma bulunmaktadır (Ağaoğlu vd., 2012; Ağaoğlu, Gültekin ve Çubukçu, 2002; Akbaşlı ve Diş, 2019; Karadağ, 2011; Yıldıım ve Aslan, 2008). Bu çalışmalarda da yöneticilerin yeterliklerinin birçok boyutta ve birçok bakış açısına göre incelendiği söylenebilir.

Öğretmen yeterliklerinin açık, şeffaf bir şekilde öğretmenlerle paylaşılması MEB (2017) tarafından da belirtildiği üzere öğretmenlerin öz değerlendirme ve kariyer planlaması yapabilmelerinde yardımcı olmaktadır (Buldu, 2014). Aynı şekilde öğretmenlik becerileri ve bilgisinin öğretmenlerle paylaşılması kariyerleri süresince mesleki gelişimlerine rehberlik edecek bir çerçeve işlevi görmektedir (OECD, 2005; akt. Çelik vd. 2019). Bu bağlamda öğretmenlerin mesleki gelişimi açısından öğretmen yeterlikleri ele alındığında çarpıcı sonuçlar ulaşıımıştır. Uştu, Taş ve Sever (2016) öğretmenlerin mesleki gelişimini engelleyen faktörlerden bazılarının kendilerini yeterli görmeleri ve mesleki gelişimi gereksiz bulmaları şeklinde bulgulara ulaşmışı ır. Benzer şekilde Özoğlu (2010), öğretmenlerin kendini geliştirme intiyacı hissetmediğini ifade etmiştir. Yeterliklerin, mesleki gelişim haricinde birçok alanda kullanıma açık olması rağmen istenilen düzeyde kullanılamadığı söylenebilir. Literatürde yeterliklerin kullanımına ilişkin çalışmalar yapılmadığı yönünde eleştiriler vardır (Atik Kara, 2012). Ayrıca yeterliklerin nasıl uygulamaya konulması gerektiğinin bilinmemesi söz konusudur (Özoğlu, 2010). Öğretmen yeterliklerinin incelenmesi, derinlemesine bilgi sunması açısından yeterliklerin birçok alanda kullanımı adına bir katkı sağlayacaktır. Bu doğrultuda çalışmanın amacı uzun bir aradan sonra güncellenmiş olan Öğretmenlik Mesleği Genel Yeterliklerinin incelenmesidir.

\section{Yöntem}

Bu bölümde, araştırmanın modeli, verilerin toplanması ve verilerin analizine dair bilgiler sunulmuştur.

\section{Araştırma Modeli}

Çalışma nitel araştırma modeli benimsenerek gerçekleştirilmiştir. Nitel araştırmalarda verilerin kod ve kategorilerin temelinde sonuçların sunulması sağlanmaktadır. Bu açıdan çalışmanın amacına yönelik dokümanların derinlemesine incelenmesi ve yorumlanması adına nitel araștırma modeli tercih edilmiştir. Doküman incelemesi, araştırma verilerinin birincil kaynağı olarak çeşitli dokümanların toplanması, gözden geçirilmesi, sorgulanması ve analizi olarak tanımlanan bir araştırma yöntemidir (Özkan, 2019). Çalışma kapsamında araştırılması amaçlanan olgu veya olgular hakkında bilgi içe- 
ren yazılı materyallerin analizini ifade etmektedir ve doküman analizi sayesinde ilgili konuda çeşitli kaynaklar tarafından geniş bir zaman diliminde üretilen birçok doküman incelenebilmektedir (Yıldırım ve Şimşek, 2008).

\section{Verilerin Toplanması}

Verilerin toplanması doküman incelemesi yoluyla gerçekleştirilmiştir. Doküman incelemesi, nitel araştırmalarda gözlem, görüșme vb. veri toplama tekniklerini zenginleştirme amacıyla kullanılabileceği gibi yalnız başına da bir veri toplama yöntemi olarak tercih edilmektedir. Bu çalışmada doküman incelemesinde çeşitli aşamalarda gerçekleştirilmiştir (Forster, 1995; Rowlinson, 2004). Öncelikle Millî Eğitim Bakanlığı resmî web sitesi aracılığıyla ulaşılan Öğretmenlik Mesleği Genel Yeterlikleri dokümanlarına ulaşılmıştır. Elde edilen dokümanların orijinalliği kontrol edilmiştir. Son olarak geliştirilen sınıflama formu aracılığıyla çözümlemeler yapılmıştır.

\section{Verilerin Analizi}

Çalışma kapsamında elde edilen dokümanlar betimsel analiz tekniği kullanılarak çözümlenmiştir. Betimsel analiz, nitel analizde, kelimeler, ifadeler, kullanılan dil, diyalogların yapısı ve özellikleri, sembolik anlatımlar ve benzetmelere dayanan bir analiz tekniğidir (Kümbetoğlu, 2005). Betimsel analizin gerçekleştirilmesinde çerçeve oluşturma, tematik çerçeveye göre verilerin işlenmesi, bulguların tanımlanması ve bulguların yorumlanması aşamaları izlenmiştir (Yıldırım ve Şimşek, 2008).

\section{Araştırma Etiği}

Yapılan bu çalışmada "Yükseköğretim Kurumları Bilimsel Araștırma ve Yayın Etiği Yönergesi" kapsamında uyulması belirtilen tüm kurallara uyulmuştur. Yönergenin ikinci bölümü olan "Bilimsel Araştırma ve Yayın Etiğine Aykırı Eylemler" başlığı altında belirtilen eylemlerden hiçbiri gerçekleştirilmemiştir.

\section{Bulgular}

Bu bölümde çalışmanın amacı doğrultusunda MEB tarafından hazırlanan 2006 ve 2017 yılında yürürlüğe konulmuş Öğretmenlik Mesleği Genel Yeterliklerine [ÖMGY] ilişkin bulgular sunulmuştur. Bulgular sayısal bilgiler, yeterlik alanları, alt yeterlikler ve performans göstergeleri olarak dört kısımda incelenmiştir. İlk olarak Millî Eğitim Bakanlığı tarafından 2006 yılında Öğretmenlik Mesleği Genel Yeterlikleri, altı yeterlik alanı, bunlara bağlı 31 alt yeterlik ve 233 performans göstergesi olarak belirlenmiştir. Bu yeterlik alanları ve alt yeterlikler Tablo 1'de sunulmuşstur.

2006 Öğretmenlik Mesleği Genel Yeterlikleri (i) kişisel ve mesleki değerler - mesleki gelişim, (ii) öğrenciyi tanıma, (iii) öğretme ve öğrenme süreci, (iv) öğrenmeyi, gelişimi izleme ve değerlendirme, (v) okul, aile ve toplum ilişkileri, (vi) program ve içerik bilgisi olmak üzere altı yeterlik alanından oluşmaktadır.

2017 yılında belirlenen Öğretmenlik Mesleği Genel Yeterlikleri ise birbiriyle ilişkili ve birbirini tamamlayan üç yeterlik alanı, bunlar altında yer alan 11 alt yeterlik ve bu yeterlikleri ilişkin 65 yeterlik göstergesinden oluşmaktadır. Üç yeterlik alanı ve 11 alt yeterlik Tablo 2'de görülmektedir.
Genel yeterliklerde sayısal olarak görülen bu farkın yanı sıra, her bir öğretmenlik alanına ayrı Özel Alan Yeterlikleri belirlemek yerine genel yeterliklerin alan bilgisi ve alan eğitimi bilgisini içerecek şekilde güncellendiği ifade edilmiştir. Her bir öğretmenlik alanına ayrı Özel Alan Yeterlikleri belirlemek yerine genel yeterliklerin alan bilgisi ve alan eğitimi bilgisini içerecek şekilde güncellenmiștir. Hem genel hem özel alan yeterliklerinin tek bir dokümanda birleştirilmesine rağmen sayısal olarak büyük bir fark görülmektedir. Bu bağlamda yeterliklerin büyük ölçüde sadeleştirildiği söylenebilir.

Yeterlik alanları genel olarak incelendiğinde altı yeterlik alanına göre daha bütüncül üç yeterlik alanının seçildiği görülmektedir. Bu açıdan öğretmen yeterliği tanımına uygun şekilde bir uzmanlık mesleği olarak öğretmenlerin sahip olması gereken bilgi, beceri ve tutumlara yer verilmiştir. Özel Alan Yeterliklerinin kaldırılması ve genel yeterliklerle bütünleştirilmesi Mesleki Bilgi yeterlik alanı altında Alan Bilgisi ve Alan Eğitimi Bilgisi alt yeterlikleri ile sağlanmıştır. Ancak Mesleki Beceri yeterlik alanı altında da alan ifadesi geçen yeterlik göstergeleri bulunmaktadır.

Planlarını alanın öğretim programına uygun olarak hazırlar. (2017- B1.1)

Alanının eğitimi ve öğretimi için gerekli becerileri sergiler (2017- B3.1)

2006 ÖMGY'de Kişisel ve Mesleki Değerler - Mesleki Gelişim altında yer alan alt yeterliklere Tutum ve Değerler altında yer verilmiştir. Ancak Mesleki Yasaları İzleme, Görev ve Sorumlulukları Yerine Getirme alt yeterliği sınırlandırılarak 2017 ÖMGY'de Mevzuat Bilgisi alt yeterliği olarak Mesleki Bilgi yeterlik alanı altına taşınmıştır. Benzer şekilde 2006 ÖMGY Öğrenciyi Tanıma yeterlik alanı içerisindeki alt yeterlikler 2017'de farklı yeterlik alanlarına entegre edilmiş ve bir kısmı Öğrenciye Yaklaşım alt yeterliği olarak Tutum ve Değerler yeterlik alanında yer bulmuştur. Ancak öğrencilerin gelişim özelliklerini tanıma alt yeterliği ve performans göstergelerine denk olabilecek yeterlik göstergelerine 2017 ÖMGY'de rastlanamamıştır.

Öğretmenin sınıf içi ve sınıf dışı uygulamalarıyla ilgili eğitim öğretimi planlama, öğrenme ortamları oluşturma, öğretme ve öğrenme sürecini yönetme ile izleme ve değerlendirme alt yeterlikleri 2017 ÖMGY'de Mesleki Beceri yeterlik alanı altında toplanmıştır. Program ve İçerik Bilgisi yeterlik alanı kapsamındaki Türk Milli Eğitiminin Amaçları ve Illkeleri adı verilmiş olan alt yeterlik ve performans göstergeleri 2017 ÖMGY'de Mevzuat Bilgisi alt yeterliği kapsamında yüzeysel şekilde yansıtıldığı görülmektedir. Bunun yanı sıra alan eğitimi programına ilişkin alt yeterlikler ise, 2019 ÖMGY'de alan eğitimi alt yeterliğinde yer bulmuştur.

Yeterlik alanlarının isimlendirilmesi bilgi, beceri ve tutum ayrımını gösterse de alt yeterliklerin ve yeterlik göstergelerinin birbirinden bağımsız olmadığı söylenebilir. Bu açıdan alan bilgisi ve alan eğitimi bilgisinin mesleki beceri boyutunda da yer alması kaçınılmazdır. 2006 ÖMGY yeterlik alanları altında da bu ayrışmanın kaçınılmazlığı göz ardı edilmemiştir. Bu durum, birbirleriyle ilintili olduğu belirlenen performans göstergelerinin yanına ilişkili olan performans göstergesine ait kod not edilerek vurgulanmıştır. Aşağıda buna dair sunulan bir örnek bulunmaktadır. 
Tablo 1. 2006 Öğretmenlik Mesleği Genel Yeterlikleri ve Alt Yeterlikleri

\begin{tabular}{|c|c|}
\hline Yeterlik Alanı & Alt Yeterlikler \\
\hline \multirow{8}{*}{$\begin{array}{l}\text { A. Kișisel ve Mesleki Değerler - } \\
\text { Mesleki Gelişim }\end{array}$} & 1.1 Öğrencilere değer verme, anlama ve saygı gösterme \\
\hline & 1.2 Öğrencilerin öğrenebileceğine ve başaracağına inanma \\
\hline & 1.3 Ulusal ve evrensel değerlere önem verme \\
\hline & 1.4 Öz değerlendirme yapma \\
\hline & 1.5 Kişisel gelişimi sağlama \\
\hline & 1.6 Mesleki gelişmeleri izleme ve katkı sağlama \\
\hline & 1.7 Okulun iyileştirilmesine ve geliştirilmesine katkı sağlama \\
\hline & 1.8 Mesleki yasaları izleme, görev ve sorumlulukları yerine getirme \\
\hline \multirow{4}{*}{ B. Öğrenciyi Tanıma } & 2.1 Gelişim özelliklerini tanıma \\
\hline & 2.2 Ilgi ve intiyaçları dikkate alma \\
\hline & 2.3 Öğrenciye değer verme \\
\hline & 2.4 Öğrenciye rehberlik etme \\
\hline \multirow{7}{*}{ C. Öğretme ve Öğrenme Süreci } & 3.1 Dersi planlama \\
\hline & 3.2 Materyal hazırlama \\
\hline & 3.3 Öğrenme ortamlarını düzenleme \\
\hline & 3.4 Ders dışı etkinlikleri düzenleme \\
\hline & 3.5 Bireysel farklılıkları dikkate alarak öğretimi çeşitlendirme \\
\hline & 3.6 Zaman yönetimi \\
\hline & 3.7 Davranış yönetimi \\
\hline \multirow{4}{*}{$\begin{array}{l}\text { D. Öğrenmeyi, Gelişimi İzleme } \\
\text { ve Değerlendirme }\end{array}$} & 4.1 Ölçme ve değerlendirme yöntem ve tekniklerini belirleme \\
\hline & 4.2. Değişik ölçme tekniklerini kullanarak öğrencinin öğrenmelerini ölçme \\
\hline & 4.3 Verileri analiz ederek yorumlama, öğrencinin gelişimi ve öğrenmesi hakkında geri bildirim sağlama \\
\hline & 4.4 Sonuçlara göre öğretme-öğrenme sürecini gözden geçirme \\
\hline \multirow{5}{*}{ E. Okul, Aile ve Toplum İlişkileri } & 5.1 Çevreyi tanıma \\
\hline & 5.2 Çevre olanaklarından yararlanma \\
\hline & 5.3 Okulu kültür merkezi durumuna getirme \\
\hline & 5.4 Aileyi tanıma ve ailelerle ilişkilerde tarafsızlık \\
\hline & 5.5 Aile katılımı ve işbirliği sağlama \\
\hline \multirow{3}{*}{ F. Program ve İçerik Bilgisi } & 6.1 Türk Milli Eğitiminin amaçları ve ilkeleri \\
\hline & 6.2 Özel alan öğretim programı bilgisi ve uygulama becerisi \\
\hline & 6.3 Özel alan öğretim programını izleme değerlendirme ve geliştirme \\
\hline
\end{tabular}

Tablo 2. 2017 Öğretmenlik Mesleği Genel Yeterlik Alanları ve Yeterlikler

\begin{tabular}{|c|c|}
\hline Yeterlik Alanı & Alt Yeterlikler \\
\hline \multirow{3}{*}{ A Mesleki Bilgi } & A1. Alan Bilgisi \\
\hline & A2. Alan Eğitimi Bilgisi \\
\hline & A3. Mevzuat Bilgisi \\
\hline \multirow{3}{*}{ B Mesleki Beceri } & B1. Eğitimi Öğretimi Planlama \\
\hline & B3. Öğretme ve Öğrenme Sürecini Yönetme \\
\hline & B4. Ölçme ve Değerlendirme \\
\hline \multirow{4}{*}{ C Tutum ve Değerler } & C1. Milli, Manevi ve Evrensel Değerler \\
\hline & C2. Öğrenciye Yaklaşım \\
\hline & C3. İletişim ve İşbirliği \\
\hline & C4. Kişisel ve Mesleki Gelişim \\
\hline
\end{tabular}


Tablo 3. 2006 ve 2017 Öğretmenlik Mesleği Genel Yeterliklerine Ilişsin Sayısal Bilgiler

\begin{tabular}{lrrr}
\hline & 2017 & 2006 & 6 \\
\hline Yeterlik Alanı & 3 \\
\hline Alt Yeterlik & 11 & 31 \\
\hline Performans/Yeterlik Göstergeleri & 65 \\
\hline
\end{tabular}

Ders planında izleme ve değerlendirme etkinliklerini belirtir (D1.2 - D1.4). (2006-C1.10)

Amaca uygun ölçme araçları belirler. (2006- D1.2)

Çok yönlü değerlendirme için alternatif ölçme araçlarını belirler (Portfolyo, kavram haritaları, gezi, gözlem, görüşme vb.). (2006- D1.4)

Performans/yeterlik göstergeleri açısından 2006 ve 2017 ÖMGY incelendiğinde temel düzeyde olan göstergelerin birleştirilerek daha karmaşık ifadelere dönüştüğü görülmektedir. Öncesinde birden fazla performans göstergesi ile ifade edilen bilgi ve beceriler tek bir yeterlik göstergesi olarak düzenlenmiștir. Buna ilişkin örnekler șu şekilde sunulmuştur.

Ölçme aracını geliştirir (2006- D2.1)

Ölçme aracının geçerlilik ve güvenirliğini test eder (2006- D2.2)

Ölçme aracını uygular (2006- D2.3)

Alanına ve öğrencilerin gelişimsel özelliklerine uygun ölçme ve değerlendirme araçları hazırlar ve kullanır (2017- B4.1)

Öğretmenlik meslek becerilerini vurgulayan performans/ yeterlik göstergeleri incelendiğinde 2017 göstergelerinin daha öncesinde de belirtildiği üzere daha üst düzey becerileri ifade ettiği görülmektedir. Benzer becerileri vurgulayan performans/yeterlik göstergelerinin geçirdiği değişim aşağıdaki örneklerde görülebilir.

\section{Ders planını öğrenciyi merkeze alarak hazırlar. (2006- C1.1)}

Öğrenme ortamlarını etkinlik türüne göre düzenler. (2006C3.2)

Bireysel öğrenme planları yapar. (2006- C5.6)

Öğrencilerin bireysel farklııklarını ve sosyokültürel özelliklerini dikkate alarak esnek öğretim planları hazırlar. (2017- B1.3)

Öğrenme ortamlarını öğrencilerin bireysel farklııklarını ve intiyaçlarını dikkate alarak düzenler. (2017- B2.3)

Performans/yeterlik göstergeleri, tarihsel olarak bakıldığında 2006 ÖMGY'de performans göstergeleri olarak adlandırılmakta ve binişik olmayan ifadelerle ortaya konmuştur. 2017 ÖMGY'de ise kavramsal bir değişime gidilerek yeterlik göstergeleri olarak belirtilmiş ve ifadeler daha karmaşık hale getirilmiştir. Bu değişikliğe rağmen performans/ yeterlik göstergelerinin somut şekilde ölçülmekten uzak olduğu söylenebilir.

Öğrencilerde öğrenmeye ilişkin olumlu tutum geliştirmeyi amaçlar. (2006- A2.1)

Materyal hazırlarken çevre olanaklarından faydalanır. (2006C2.7)

Özel alan öğretim programındaki değişimleri izler. (2006- F3.1)
Alanındaki temel kuram ve yaklașımların alanına yansımalarını yorumlar. (2017- A1.2)

Öğrencilerin üst düzey bilişsel becerilerini geliştirici öğrenme ortamları olușturur. (2017- B2.6)

Meslektaşlarılyla bilgi ve deneyim paylaşımına açılktır. (2017C3.4)

Her iki Öğretmenlik Mesleği Genel Yeterlikleri açısından bakıldığında bilgi ve iletişim teknolojileri, öğretim teknolojileri açısından yeterli önemin gösterilmediği söylenebilir. 2006 ÖMGY içerisinde teknoloji vurgusu yer yer yapılmakta, öğretmenlerin teknoloji okuryazarı olması gerektiğine dair göstergelere yer verilmektedir. Buna karşılık 2017 ÖMGY'de teknolojiye atıfta bulunan tek bir yeterlik göstergesi bulunmaktadır

Öğrenme ve öğretme sürecinde bilgi ve iletişim teknolojilerini etkin olarak kullanır. (2017- B4.9)

Yeterlik dokümanları öğretmenlik mesleğinin gerektirdiği bilgi, beceri, tutum, değer, davranış vb. birçok ifadeyi performans/yeterlik göstergesi olarak yeterlik alanları ve alt yeterlikler kapsamında sunmaktadır. Ancak bu dokümanların öğretmenlerden beklenenleri listelediği ve kısaca açıkladığı söylenebilir.

\section{Tartışma, Sonuç ve Öneriler}

Bu çalışma Türkiye'de öğretmenlik mesleği ve öğretmen yetiștirme bașta olmak üzere birçok alanda önemli dokümanlardan biri olan Öğretmenlik Mesleği Genel Yeterlikleri dokümanlarının incelenmesi amaçlanmıștır. Bu amaca yönelik olarak 2006 ve 2017 yıllarında yürürlüğe konulan Öğretmenlik Mesleği Genel Yeterlikleri dokümanları yeterlik alanları, alt yeterlikler ve performans göstergeleri bağlamında analiz edilmiştir.

Ilk bulgular yıllara göre yeterlik alanları, alt yeterlikler ve performans göstergeleri bağlamında sayısal olarak bir azalma görülmüştür. Bu azalma bir sadeleşme olarak değerlendirilebileceği gibi, nitelik açısından incelendiğinde ise özellikle performans göstergelerinin bütünleştirilerek daha az sayıda göstergeye ulaşıldığı söylenebilir. Ancak yine de bu sadeleștirilme ile kısmen de olsa yeterliklerinin kapsamının daraltıldığı görülmektedir.

Yeterlik alanlarının isimlendirilmesinde literatüre benzer şekilde bilgi, beceri, tutum ve değerler kavramlarının kullanılması eğitim bilimleri ve öğretmen yetiştirmede kavram bütünlüğü açısından olumlu bir gelişme olarak görülebilir. $\mathrm{Bu}$ açıdan yeterlik alanların Mesleki Bilgi, Mesleki Beceri ve Tutum ve Değerler olarak isimlendirilmesi yerinde kabul edilmekle birlikte bu düzenlemenin beraberinde kavramların içinin doldurularak ile sürdürülmesi beklenmektedir. Aynı zamanda MEB Öğretmenlik Mesleği Genel Yeterliklerini söz konusu üç yeterlik alanı ile ifade etmesine rağmen, 
güncel öğretmen yetiştirme programlarında öğretmenlikle ilgili alan bilgisi, pedagoji bilgisi ve pedagojik alan bilgisi olmak üzere üç bilgi ve yeterlik alanı olduğu belirtilmiştir. MEB ve literatürdeki çoğu araştırma tarafından öğretmen yeterlikleri konusunda altı çizilen MEB ve YÖK işbirliğinin hayata geçirilemediği görülmektedir. Zira MEB (2006; 2017) öğretmen yetiştirme açısından ulusal ortak terim ve tanımlamaları içeren bir dil birliğinin sağlanmasını amaçlamış ancak YÖK Öğretmenlik Mesleği Genel Yeterliklerinin dikkate alındığını belirtmesine rağmen öğretmen yetiștirme programlarını farklı bir kavramsal yapıda kurgulamıştır.

2006 Öğretmenlik Mesleği Genel Yeterliklerinde performans göstergesi, yeterliklerin gerçekleşip gerçekleşmediğinin delili olabilecek ölçülebilir davranışlar olarak tanımlanmıştır (MEB, 2006). 2017 yılında ise bu kavram yerine yeterlik göstergesi kavramına yer verilmiş ve yeterliklere sahip olma düzeyini ortaya koyan bilgi, beceri, tutum ve davranışlar olarak açıklanmıştır (MEB, 2017). Bu kavramsal değişim, performans göstergesi olarak yer verilen ifadelerin gözlem ve ölçme zorluğundan kaynaklanmış olabilir. Bu açıdan, yeterlik göstergesi ile somut, ölçülebilir olduğu yönünde vurgu yapılmayan daha soyut bir kavrama geçiş yapılmıştır. Ancak her iki kavram da öğretmen yeterlikleri altında yer alan göstergelerinde bilgi, tutum, değer ve inançların iç içe geçtiği ve ayrıştırılamadığı yönündeki eleştirileri ortadan kaldıramamaktadır (TED, 2009). Dünyadan örnekler incelendiğinde InTASC (2013) öğretmen standartlarını temel bilgiler, önemli noktalar ve performans göstergeleri olmak üzere 3 ayrı boyutta şekillendirmiştir. Dolayısıyla performans göstergeleri öğretmen standartlarının yalnızca davranışa dönük ve ölçülebilir kısmını yansıtmaktadır. Bilgilerin testler ile; tutum, değer ve inançların derecelendirme ölçekleri dolaylı olarak ölçülebildiği göz önünde bulundurulduğunda, söz konusu olan bilgi, tutum, değer ve inançlara sahip olan öğretmenlerin bunları davranışa dönüştürmesi önem kazanmaktadır. Performans göstergelerinin somut ölçülebilir ve gözlenebilir davranış, iş ve eylemler olarak ifade edilmesi önerilmektedir (TED, 2009).

Öğretmenlik Mesleği Genel Yeterlikleri performans/yeterlik göstergeleri incelendiğinde yeterlik göstergelerinin birden fazla ifadeyi kapsayacak nitelikte, karmaşık hale geldiği sonucuna ulaşılmıştır. 2006 performans göstergelerine nazaran, 2017 yeterlik göstergelerinin daha üst düzey becerileri içerdiği söylenebilir. Fakat dünyadaki öğretmen yeterlikleri/ standartları ile karşılaştırıldığında öğretmenlik alanına özgü becerilerin daha üst düzeyde ölçülmesi gerekliliği ön plana çıkmaktadır (Çubukçu, Tosuntaş ve Kırcaburun, 2017). Özellikle performans değerlendirme uygulamalarında performans/yeterlik göstergelerinin kullanılabilmesi bağlamında göstergelerin daha işlevsel olması gerekmektedir.

Son olarak Öğretmenlik Mesleği Genel Yeterliklerinin önemli kullanım alanlarından biri olan ve literatürde de geniş yer bulan mesleki gelişimi destekleyecek yapıda olması Önemlidir. 2006 ve 2017 Öğretmenlik Mesleği Genel Yeterlikleri, öğretmenlerin mesleki gelişim intiyaçlarını belirlemeye yönelik bir öz değerlendirme yapabilecekleri veya öğretmenlerin kendilerinden beklenenleri açıkça görebilecekleri bir referans çerçevesi olmaktan uzaktır. Öğretmenlerin yeterlik düzeylerinin belirlenmesine yönelik araştırmalarda öğretmen ve öğretmen adaylarının kendilerini yeterli gördükleri sonucuna ulaşılmıştır (Aktemür Gürler ve Tekmen, 2020; Çelik vd., 2019; Özer ve Gelen, 2008). Bu sonuçlar öğretmenlerden beklentilerin asgari düzeyde ve yüzeysel olması eleştirileriyle uyuşmaktadır (Danielson ve McGreal, 2000; Stiggens ve Duke, 1988). Öğretmenlerin kendilerini yeterli görmeleri ve kendilerini geliştirme intiyacı hissetmemeleri gibi faktörler mesleki gelişimin önüne engel olarak çıkmaktadır. Rasyonel ve optimum düzeyde belirlenen yeterlikler ise öğretmenlerin mesleki gelişim intiyacını ortaya çıkaracak bir rol üstlenebilir. Benzer şekilde performans/ yeterlik göstergelerinin öğretmenlerin gelişimini sağlayacak şekilde hazırlanması ve bu göstergelerin değerlendirmede gerçekçi şekilde kullanılması öğretmen niteliğinin arttırılmasına yarar sağlayacaktır. Öğretmen adaylarının da mesleğin gerektirdiği yeterlikler konusunda hizmet öncesinde bilgi sahibi olması ve öz değerlendirme yapabilmeleri sağlanmalıdır. Son olarak yeterliklerin öğretmenler ve öğretmen adaylarına hem kılavuz hem değerlendirme kriteri işlevi görecek şekilde yapılandırılması önerilebilir.

\section{Yayın Etiği Beyanı}

Yapılan bu çalışmada "Yükseköğretim Kurumları Bilimsel Araştırma ve Yayın Etiği Yönergesi" kapsamında uyulması belirtilen tüm kurallara uyulmuştur. Yönergenin ikinci bölümü olan "Bilimsel Araştırma ve Yayın Etiğine Aykırı Eylemler" başlığı altında belirtilen eylemlerden hiçbiri gerçekleştirilmemiştir.

\section{Kaynakça}

Ağaoğlu, E,. Gültekin, M. ve Çubukçu, Z. (2002). Okul yöneticisi yeterliklerine dayalı eğitim programı önerisi. İçinde 21. Yüzyıl Eğitim Yöneticilerinin Yetiştirilmesi Sempozyumu Bildirileri (s. 145-161). Ankara: Ankara Üniversitesi Eğitim Bilimleri Fakültesi Yayınları.

Ağaoğlu, E., Altınkurt, Y., Yılmaz, K., ve Karaköse, T. (2012). Okul yöneticilerinin yeterliklerine ilişkin okul yöneticilerinin ve öğretmenlerin görüşleri (Kütahya ili). Eğitim ve Bilim, 37(164), 159-175

Aisyah, I., Yuliasri, I., \& Warsono, W. (2018). The professional and pedagogic competences of English teachers with different UKG (Teaching Competence Test) achievement levels. English Education Journal, 9(1), 74-83.

Akbaşlı, S. ve Diş, O. (2019). Öğretmen görüşleri doğrultusunda lider okul yöneticilerinin yeterlikleri. Uluslararası Liderlik Çalışmaları Dergisi: Kuram ve Uygulama, 2(2), 86-102.

Atik Kara, D. (2012). Öğretmenlik meslek bilgisi derslerinin öğretmen adaylarına öğrenme ve öğretme sürecine ilişkin yeterlikleri kazandırması yönünden değerlendirilmesi (Doktora tezi). Anadolu Üniversitesi Eğitim Bilimleri Enstitüsü, Eskişehir.

Gürler, S. A., ve Tekmen, B. (2020). Okul öncesi öğretmen adaylarının öğretmen yeterlilik algıları üzerine bir inceleme. Başkent University Journal of Education, 7(1), 158-168.

Buldu, M. (2014). Öğretmen yeterlik düzeyi değerlendirmesi ve mesleki gelişim eğitimleri planlaması üzerine bir öneri. Milli Eğitim, 204, 114-134. 
Bursalıoğlu, Z. (1981). Eğitim yöneticisinin yeterlikleri. Ankara: Ankara Üniversitesi Eğitim Fakültesi Yayınları.

Can, E. (2019). Öğretmenlerin meslekî gelişimleri: Engeller ve öneriler. Eğitimde Nitel Araştırmalar Dergisi, 7(4), 1618-1650.

Council of Chief State School Officers. (2013, April). Interstate teacher assessment and support consortium InTASC model core teaching standards and learning progressions for teachers 1.0: a resource for ongoing teacher development. Washington, DC: Author.

Çapri, B. ve Çelikkaleli, Ö. (2008). Öğretmen adaylarının öğretmenliğe ilişkin tutum ve mesleki yeterlik inançlarının cinsiyet program ve fakültelerine göre incelenmesi. Inönü Üniversitesi Eğitim Fakültesi Dergisi, 9(15), 33-53.

Çelik, Ö., Yorulmaz, A., ve Çokçalışkan, H. (2019). Öğretmen genel yeterlikleri açısından sınıf öğret-menleri ve öğretmen adaylarının kendilerini değerlendirmeleri. Eskişehir Osmangazi Üniversitesi Sosyal Bilimler Dergisi, 20, 203-215

Çubukçu, F. (2010). Student teachers' perceptions of teacher competence and their attributions for success and failure in learning. The Journal of International Social Research, 3(10), 213-217.

Çubukçu, Z., Tosuntaş, Ş. B., \& Kırcaburun, K. (2017). Comparison of Turkey and United States in terms of teacher performance indicators. Journal of Pedagogical Research, 1(1), 64-76.

Danielson, C.,\& McGreal, T. L. (2000). Teacher evaluation to enhance professional practice. Alexandria, VA: Association for Supervision and Curriculum Development.

Demirtaş, H., Cömert, M., \& Özer, N. (2011). Öğretmen adaylarının özyeterlik inançları ve öğretmenlik mesleğine ilişkin tutumları. Eğitim ve Bilim, 36(159), 96-111.

Devlet Planlama Teşkilatı. (2000). Sekizinci beş yılık kalkınma planı 2001-2005. Ankara: Devlet Matbaası.

Devlet Planlama Teşkilatı. (2006). Dokuzuncu kalkınma planı 2007-2013. Ankara: Devlet Matbaası.

Dilci, T., ve Yıldız, H. (2012). Öğretmen adaylarının mesleki yeterliklerine ilişkin inançları. Sosyal Bilimler Araştırmaları Dergisi, 7(1), 245-265.

EARGED (2006). Okulda performans yönetimi modeli. Ankara: Milli Eğitim Basımevi Müdürlüğü.

Erişen, Y. ve Çeliköz, N. (2003). Öğretmen adaylarının genel öğretmenlik davranışları açısından kendilerine yönelik yeterlilik algıları. Türk Eğitim Bilimleri Dergisi, 1(4), 427- 439.

Forster, N. (1995). The analysis of company documentation. C. Cassell \& G. Symon (Eds). Qualitative methods in organizational research: A practical guide. London: Sage Publications
Gündoğdu, K., Aytaçlı, B., Aydoğan, R., ve Yıldırım, C. (2015). Öğretmen yeterlikleri alanında yazılan makalelerin içerik analizi. Adnan Menderes Üniversitesi Eğitim Fakültesi Eğitim Bilimleri Dergisi, 6(2), 30-43.

İyison, G., ve Onur-Sezer, G. (2017). Sınıf öğretmeni adaylarının öğretmenlik mesleğine yönelik tutumları ile ilkokul öğretmenlerinin yeterlilikleri arasındaki ilişkinin incelenmesi. Akademik Sosyal Araştırmalar Dergisi, (50), 528-542.

Kalkınma Bakanlığı (2013). Onuncu Kalkınma Planı 2014-2018. Ankara: Devlet Matbaası

Karacaoğlu, O. C. (2008). Öğretmenlerin yeterlik algıları. Yüzüncü Yıl Üniversitesi Eğitim Fakültesi Dergisi, 5(1), 72-78.

Karadağ, E. (2011). Okul müdürlerinin niteliklerine ilişkin olarak öğretmenlerin oluşturdukları bilişsel kurgular: Fenomonolojik bir çözümleme. Eğitim ve Bilim, 36(159), 25-40.

Karakuş, ì. (2017). Öğretmen adaylarının öz yeterlik algıları ile öğretmenlik mesleğine yönelik tutumlarının incelenmesi. Kesit Akademi Dergisi, (9), 361-377.

Kararmaz, S. ve Arslan, A. (2014). Illköğretim İngilizce öğretmenlerinin öğretmenlik mesleği özel alan yeterliklerine ilişkin algılarının belirlenmesi. Uşak Üniversitesi Sosyal Bilimler Dergisi, 7(4), 203-232.

Kazu, í. Y. ve Çam, H. (2019). Öğretmen yeterliği ve nitelikleri üzerine yapılmış lisansüstü çalışmaların incelenmesi: bir içerik analizi çalışması. Electronic Journal of Social Sciences, 18(71), 1349-1367.

Kümbetoğlu, B. (2005). Sosyolojide ve antropolojide niteliksel yöntem ve araştırma. İstanbul: Bağlam.

Milli Eğitim Bakanlığı (MEB). (1973). Milli Eğitim Temel Kanunu. Resmi Gazete (Sayı: 1739). 1 Şubat 2020 tarihinde http://oygm.meb.gov.tr/meb_iys_dosyalar /2017_11/08144011_KANUN.pdf adresinden erişildi.

Millî Eğitim Bakanlığı (MEB). (2006). Öğretmen yeterlikleri. Ankara: Devlet Kitaplar Müdürlüğü.

Millî Eğitim Bakanlığı (MEB). (2017). Öğretmenlik mesleği genel yeterlikleri. Ankara: Öğretmen Yetiştirme ve Geliştirme Genel Müdürlüğü.

Mutlu, N. (2016). Okul öncesi öğretmenlerinin mesleki yeterlilik algılarının belirlenmesi (Yüksek lisans tezi). Yakındoğu Üniversitesi, Eğitim Bilimleri Enstitüsü, Kıbrıs.

Özer, B., ve Gelen, İ. (2008). Öğretmenlik mesleği genel yeterliklerine sahip olma düzeyleri hakkında öğretmen adayları ve öğretmenlerin görüşlerinin değerlendirilmesi. Mustafa Kemal Üniversitesi Sosyal Bilimler Enstitüsü Dergisi, 5(9), 39-55.

Özoğlu, M. (2010). Türkiye'de öğretmen yetiştirme sisteminin sorunları. Ankara: Siyaset, Ekonomi ve Toplum Araştırmaları Vakfı. 
Pantić, N., \& Wubbels, T. (2010). Teacher competencies as a basis for teacher education - Views of Serbian teachers and teacher educators. Teaching and Teacher Education, 26(3), 694-703.

Rahmani, B. D., \& Alyani, F. (2020). Structural equation modelling (sem) on teacher competencies test of Indonesian EFL senior high school teachers. Journal of Education Research and Evaluation, 4(2), 103-108.

Rowlinson, M. (2004). Historical analysis of company documents. C. Cassell \& G. Symon (Eds). Essential guide to qualitative methods in organizational research (s. 301312). London: Sage Pub.

Şahin, A. E. (2004). Öğretmen yeterliklerinin belirlenmesi. Bilim ve Aklın Aydınlığında Eğitim Dergisi, 5(58), 58-62.

Şeker, H., Deniz, S., ve Görgen, i. (2005). Tezsiz yüksek lisans öğretmen adaylarının öğretmenlik yeterlikleri üzerine değerlendirmeleri. Kuram ve Uygulamada Eğitim Yönetimi Dergisi, 42, 237-253

Şişman, M. (2002). Öğretmenliğe giriş. Ankara: Pegem Yayıncılık.

Taşar, H. H. (2012). illköğretim okullarında çalışan öğretmenlerin mesleki yeterlik algılarının incelenmesi (Adıyaman ili örneği). Verimlilik Dergisi, 2012(4), 67-77.

Taşgın, A. (2010). Öğretmenlik mesleği genel yeterliklerinden; öğretme ve öğrenme süreci yeterlikleri ile öğrenmeyi, gelişimi izleme ve değerlendirme yeterliklerinin sınıf öğretmenleri ve sınıf öğretmeni adaylarının görüşlerine göre değerlendirilmesi (Yüksek lisans tezi). Atatürk Üniversitesi, Erzurum.

Türk Eğitim Derneği (TED). (2009). Öğretmen yeterlikleri. Ankara: Türk Eğitim Derneği.

Uştu, H., Mentiş Taș, A., ve Sever, B. (2016). Öğretmenlerin mesleki gelişime yönelik algılarına ilişkin nitel bir araştırma. Elektronik Mesleki Gelişim ve Araştırma Dergisi, 1, 15-23.

Yeşilyurt, E. (2011). Öğretmen adaylarının öğretmenlik mesleğinin genel yeterliklerine yönelik yeterlik algıları. Türk Eğitim Bilimleri Dergisi, 9(1), 71-100.

Yıldırım, A. ve Șimşek, H. (2008). Sosyal bilimlerde nitel araştırma yöntemleri. Ankara: Seçkin.

Yıldırım, N. ve Aslan, B. (2008). ilköğretim okulu müdürlerinin yeterlikleri ile öğrenme stillerine ilişkin bir araştırma (Tokat ili örneği). Elektronik Sosyal Bilimler Dergisi, $7(24), 238-255$.

Yükseköğretim Kurulu. (2007). Eğitim fakültesi öğretmen yetiştirme lisans programları. 1 Şubat 2020 tarihinde https://www.yok.gov.tr/Documents/Yayinlar/ Yayinlarimiz/egitim-fakultesi-ogretmen-yetistirme-lisans-programlari.pdf adresinden erişildi.
Yükseköğretim Kurulu. (2018). Öğretmen yetiştirme lisans programları. 1 Şubat 2020 tarihinde https://www.yok. gov.tr/Documents/Kurumsal/egitim_ogretim_dairesi/Yeni-Ogretmen-Yetistirme-Lisans-Programlari/ AA_Sunus_\%20Onsoz_Uygulama_Yonergesi.pdf adresinden erişildi. 